\title{
Influence of Benzyladenine and Thidiazuron on Shoot Regeneration from Leaf and Shoot tip Explants of Sedum sarmentosum Bunge
}

\author{
Doo Hwan Kim ${ }^{1}$, Iyyakkannu Sivanessan ${ }^{2 *}$ \\ ${ }^{1}$ Konkuk University, Departament of Bio-resources and Food Science, Seoul, Korea (the Republic of). ${ }^{2}$ Konkuk \\ University, Molecular Biotechnology 1, Hwayang-dong, Seoul, Korea (the Republic of).
}

\begin{abstract}
Effects of $\mathrm{N}^{6}$-benzyladenine (BA) or thidiazuron (TDZ) on adventitious shoot regeneration and axillary shoot multiplication of Sedum sarmentosum was investigated. Leaf and shoot tip explants obtained from in vitro-grown shoots of S. sarmentosum were cultured on Murashige and Skoog (MS) medium supplemented with 0, 2.0, 4.0 or 8.0 $\mu \mathrm{M}$ BA or TDZ. Of the two cytokinins studied, BA was found to be more responsive as compared to TDZ with respect to number of shoots produced per explant. High frequency of shoot regeneration $(92.2 \%)$ with a mean of 12.3 shoots was produced when the leaf explants were cultured on MS medium supplemented with $8.0 \mu \mathrm{M}$ BA. The highest number of shoots (25.4) was obtained when shoot tip explants were cultured on MS medium devoid of cytokinins after 35 days of culture. For root induction, regenerated shoots were cultured on MS medium supplemented with 0, 2.0, 4.0 or $8.0 \mu \mathrm{M}$ indole-3-acetic acid (IAA), indole-3-butyric acid (IBA) or $\alpha$-naphthaleneacetic acid (NAA). The highest number of (17.6) roots per shoot was obtained on MS medium supplemented with $2.0 \mu \mathrm{M}$ IBA after 30 days of culture. Regenerated plantlets were successfully acclimatized in the greenhouse with $100 \%$ survival rate.
\end{abstract}

Key words: Crassulaceae, cytokinin, direct shoot regeneration, shoot multiplication, stringy stonecrop

*Authors for correspondence: isivanesan@gmail.com 


\section{INTRODUCTION}

Sedum sarmentosum Bunge (Crassulaceae) is a perennial herb commonly known as stringy stonecrop native to Eastern Asia. It is widely grown as an ornamental plant due to its attractive appearance and hardiness. The whole plant is also used in Chinese and Korean folk medicine for the treatment of chronic viral hepatitis (He et al. 1998), and the methanol extract of $S$. sarmentosum has been reported to exhibit many biological activities like anti-angiogenic, anti-inflammatory and antinociceptive (Jung et al. 2008). S. sarmentosum is normally propagated by vegetative stem cuttings or dividing its roots; however, the multiplication rate is very slow and requires a large number of parent propagules (Yang et al. 2012). Therefore, efficient large-scale propagation methods are needed. In vitro propagation could overcome this problem and used for multiplication of elite clones to fulfill the increasing demand of planting material.

There are few reports available on in vitro propagation of $S$. sarmentosum through adventitious shoot regeneration from leaf and stem explants (Ahn and Lee 2004; Lee et al. 2009), and axillary shoot multiplication from nodal explants (Lee et al. 2006). However, direct adventitious shoot regeneration from explants of $S$. sarmentosum has not been reported previously. Ahn and Lee (2004) reported that a high concentration of $\mathrm{N}^{6}$ benzyladenine $\left(\begin{array}{lllll}3.0 & \mathrm{mg} & \mathrm{l}^{-1} & \mathrm{BA}\end{array}\right)$ and $\alpha$ naphthaleneacetic acid $\left(0.2 \mathrm{mg} \mathrm{l}^{-1} \mathrm{NAA}\right)$ required for shoot regeneration from callus derived from leaf segments. However, this protocol is not suitable for shoot regeneration from callus cultures of several collections (Lee et al. 2009). The authors reported that callus induction and shoot regeneration of $S$. sarmentosum were largely affected by genotype, explant source and basal medium, and the plant regeneration efficiency seemed to be the result of an interaction among these factors. On the other hand, the determination of axillary shoot multiplication also depends upon the source of plant tissue (Lee et al. 2006). To our knowledge, shoot multiplication using shoot tip explants is not available. The objective of this study was to evaluate the effects of BA and thidiazuron (TDZ) on direct adventitious shoot regeneration and axillary shoot multiplication from leaf and shoot tip explants of S. sarmentosum.

\section{MATERIALS AND METHODS}

Seeds of S. sarmentosum were collected from healthy plants growing in the greenhouse. Seeds were surface disinfested with $70 \%(\mathrm{v} / \mathrm{v})$ ethanol for $60 \mathrm{~s}, 1.5 \%$ sodium hypochlorite $(\mathrm{NaOCl})$ solution with a drop of Tween 20 for $15 \mathrm{~min}$ and $0.01 \%$ (w/v) mercuric chloride $\left(\mathrm{HgCl}_{2}\right)$ for $10 \mathrm{~min}$. Each treatment was followed by 3-4 rinses with sterile distilled water. The seeds were germinated on Murashige and Skoog (MS) medium (Murashige and Skoog 1962) containing 3\% (w/v) sucrose and $0.8 \%(\mathrm{w} / \mathrm{v})$ agar. The $\mathrm{pH}$ of the medium was adjusted to 5.8 using $1 \mathrm{~N} \mathrm{KOH}$ prior to autoclaving at $121^{\circ} \mathrm{C}$ for $20 \mathrm{~min}$. Cultures were maintained at $25 \pm 1{ }^{\circ} \mathrm{C}$ under a $12 \mathrm{~h}$ photoperiod with $15 \mu \mathrm{mol} \mathrm{m}^{-}$ $2 \mathrm{~s}^{-1}$ photosynthetic photon flux density (PPFD) provided by cool white fluorescent light (Philips 40 $\mathrm{W}$ tubes). After 4 weeks, shoot tips isolated from seedlings were cultured on MS basal medium. The in vitro-grown shoots (5 weeks old) were used as the explant source.

Leaf $(3-5 \mathrm{~mm})$ and shoot tip $(5-10 \mathrm{~mm})$ explants were cultured on MS medium supplemented with 0 , $2.0,4.0$ or $8.0 \mu \mathrm{M}$ BA or 1-Phenyl-3-(1,2,3,thiadiazol-5-yl)urea (TDZ) for shoot induction. Cultures were maintained under a $16 \mathrm{~h}$ photoperiod with $45 \mu \mathrm{mol} \mathrm{m}^{-2} \mathrm{~s}^{-1}$ PPFD. For each treatment, 25 explants were used and the experiment was repeated three times. The number of explants initiating shoots and mean number of shoots per explant were recorded after 5 weeks of culture. Regenerated shoots $(>1.0 \mathrm{~cm}$ long) were separated from the shoot clumps and cultured on MS medium supplemented with $0,2.0,4.0$ or $8.0 \mu \mathrm{M}$ indole-3acetic acid (IAA), indole-3-butyric acid (IBA) or $\alpha$ naphthaleneacetic acid (NAA). For each treatment, 25 shoots were used and the experiment was repeated three times. After 30 days of incubation, the percentage of root induction and number of roots per shoot were recorded. Well-developed plantlets were hardened in greenhouse medium (Tosilee medium; Shinan Grow, Jinju, Korea), and transferred to the greenhouse $\left(23 \pm 5{ }^{\circ} \mathrm{C}, 60-70 \%\right.$ relative humidity), irrigated two days interval with half-strength MS basal salts solution, and the survival rate of plantlets was recorded after 30 days. All data were subjected to analysis of variance (ANOVA) by using SAS program (Release 9.2, SAS Institute, NC, USA), and were expressed as the mean \pm standard error (SE). Differences between the mean values were assessed with Duncan's multiple range test at $p \leq 0.05$. Percentage values 
were transformed using arcsine square root to normalize error distribution prior to variance analysis.

\section{RESULTS AND DISCUSSION}

Shoot formation was not observed when leaf explants were incubated on MS medium containing no cytokinins. On the other hand, the presence of BA or TDZ was effective in promoting the formation of adventitious shoots. Shoot buds occurred directly from the cut ends of explants within 2 weeks of culture. The shoot formation was significantly affected by the type and concentration of cytokinin, because uptake, transport, and metabolism differ between explants or genotypes and interaction with endogenous cytokinin (Van Staden et al. 2008). The shoot regeneration response of leaf explants varied among various BA concentrations. The mean number of shoots increased with increase in BA concentration. A maximum frequency of shoot regeneration $(92.2 \%)$ with a mean of 12.3 shoots was produced when the leaf explants were cultured on MS medium supplemented with $8.0 \mu \mathrm{M}$ BA (Table 1, Fig. 1A). The stimulating effect of BA on direct adventitious shoot regeneration has been reported in begonia (Mendi et al. 2009), Centaurea montana (Alaiwi et al. 2011), and Scrophularia takesimensis (Jeong and Sivanesan 2015), Sedum erythrostichum (Yoon et al. 2002).

Table 1- Effect of BA and TDZ on direct adventitious shoot regeneration from leaf explants of Sedum sarmentosum after 35 days of culture.

\begin{tabular}{lllll}
\hline Conc. $\mu \mathrm{M}$ & & Shoot regeneration $(\%)$ & $\begin{array}{l}\text { Number of shoots } / \\
\text { explant }\end{array}$ & \\
\hline BA & TDZ & $0.0 \pm 0.0^{\mathrm{e}}$ & $0.0 \pm 0.0^{\mathrm{d}}$ & \\
\hline 0.0 & 0.0 & $64.0 \pm 1.8^{\mathrm{d}}$ & $3.5 \pm 0.4^{\mathrm{c}}$ & \\
2.0 & 0.0 & $85.9 \pm 1.5^{\mathrm{c}}$ & $6.0 \pm 0.4^{\mathrm{b}}$ & \\
4.0 & 0.0 & $92.2 \pm 0.7^{\mathrm{b}}$ & $12.3 \pm 0.8^{\mathrm{a}}$ & \\
8.0 & 0.0 & $100 \pm 0.0^{\mathrm{a}}$ & $6.4 \pm 0.4^{\mathrm{b}}$ & \\
0.0 & 2.0 & $100 \pm 0.0^{\mathrm{a}}$ & $5.5 \pm 0.5^{\mathrm{b}}$ & \\
0.0 & 4.0 & $94.7 \pm 1.0^{\mathrm{b}}$ & $3.7 \pm 0.4^{\mathrm{c}}$ & \\
0.0 & 8.0 & & \\
\hline
\end{tabular}

Means \pm SE within a column followed by the same letters are not significantly different using Duncan's multiple range test at $\mathrm{p} \leq 0.05$.

TDZ also promoted direct adventitious shoot formation from leaf explants of $S$. sarmentosum. The frequency of shoot regeneration was promoted in the presence of TDZ. However, the supplement of TDZ produced less shoot number. The highest frequency of shoot regeneration $(100 \%)$ was observed on MS medium supplemented with 2.0 or $4.0 \mu \mathrm{M}$ TDZ (Table 1). This result was somewhat similar to that of Sedum spectabile, where the highest shoot induction (88.9\%) was obtained on MS medium supplemented with $0.6 \mathrm{mg} \mathrm{l}^{-1} \mathrm{TDZ}$ and $0.1 \mathrm{mg} \mathrm{l}^{-1}$ NAA (Yang et al. 2012). Higher TDZ (8.0 $\mu \mathrm{M})$ concentration inhibited the frequency of shoot induction $(94.7 \%)$ and mean number of shoots (3.7). Such a response had also been observed in Ajuga multiflora (Sivanesan et al. 2011) and Jeffersonia dubia (Sivanesan and Jeong 2013). Of the two cytokinins studied, BA was found to be more responsive as compared to TDZ with respect to number of shoots produced per explant.

In vitro propagation through axillary shoot proliferation is an efficient method for large-scale production of true-to-type planting material of important plants. Shoot tip explants cultured on cytokinins-free MS medium produced 5-6 shoots which branched repeatedly giving a mean of 25.4 shoots and the frequency of shoot induction was $100 \%$ (Table 2, Fig. 1B). Root formation was also observed at the base of shoot tip explants. The simultaneous formation of shoot and root system has been reported in Curcuma amada (Prakash et al. 2004). Supplementation of the culture medium with BA or TDZ did not improve shoot multiplication as compared to the control (MS medium devoid of cytokinins). Furthermore, inhibition of rooting was observed in the presence of BA or TDZ. Cytokinins are involved in various aspects of growth and development of plants, including shoot and root morphogenesis (Jeong and Sivanesan 2016). The inhibition of in vitro adventitious root formation by cytokinins seems to be a common phenomenon.

Lee et al. (2006) studied the effect of different concentrations of cytokinins $(0,0.2,0.5$ or $1.0 \mathrm{mg}$ 
$\mathrm{I}^{-1} \mathrm{BA}$ or kinetin) and reported that the highest number of shoots (5.0) was obtained when the nodal explants $S$. sarmentosum were cultured on MS medium containing $0.2 \mathrm{mg} \mathrm{l}^{-1}$ kinetin. In the present study, the frequency of shoot induction for the BA concentrations 2.0, 4.0 and $8.0 \mu \mathrm{M}$ were significantly different from each other, but the mean number of shoots regenerated (5.4-6.2) were not significantly different (Table 2). The shoot tip explants cultured on MS medium supplemented with BA produced short shoot buds which did not branched further and synthesized purple or red pigments (Fig. 1C). Of the various concentrations of TDZ studied, maximum number of shoots (18.1)
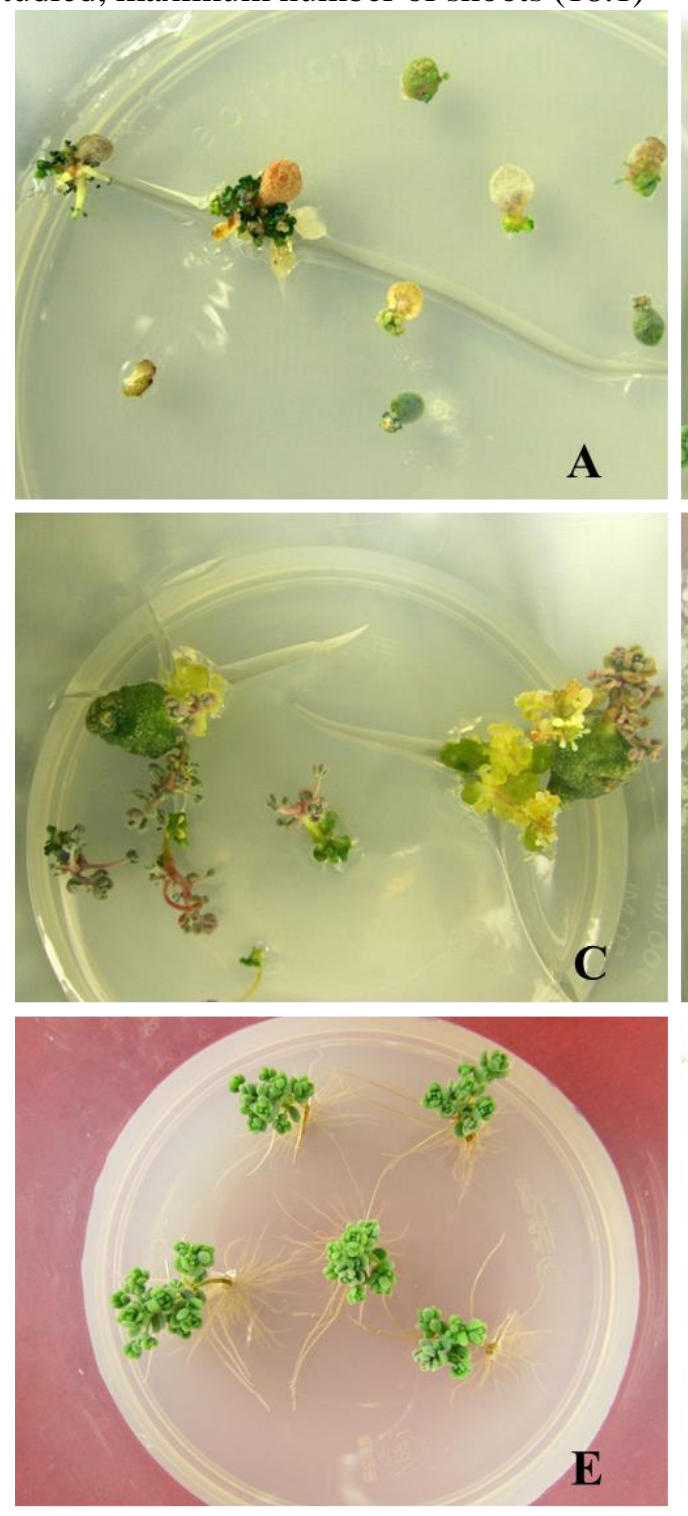

was obtained on MS medium supplemented with $2.0 \mu \mathrm{M}$ TDZ. However, most of regenerated shoot buds were stunted. TDZ has been reported to induce multiple shoots in many plants (Huetteman and Preece 1993). TDZ appears less susceptible to enzymatic degradation in vivo than other amino purine cytokinins, and thus at low concentration it can induce higher frequency of multiple shoot induction than other cytokinins (Magyar-Tabori at al. 2010). The mean number of shoots reduced on MS medium supplemented with high concentrations of TDZ (Table 2).
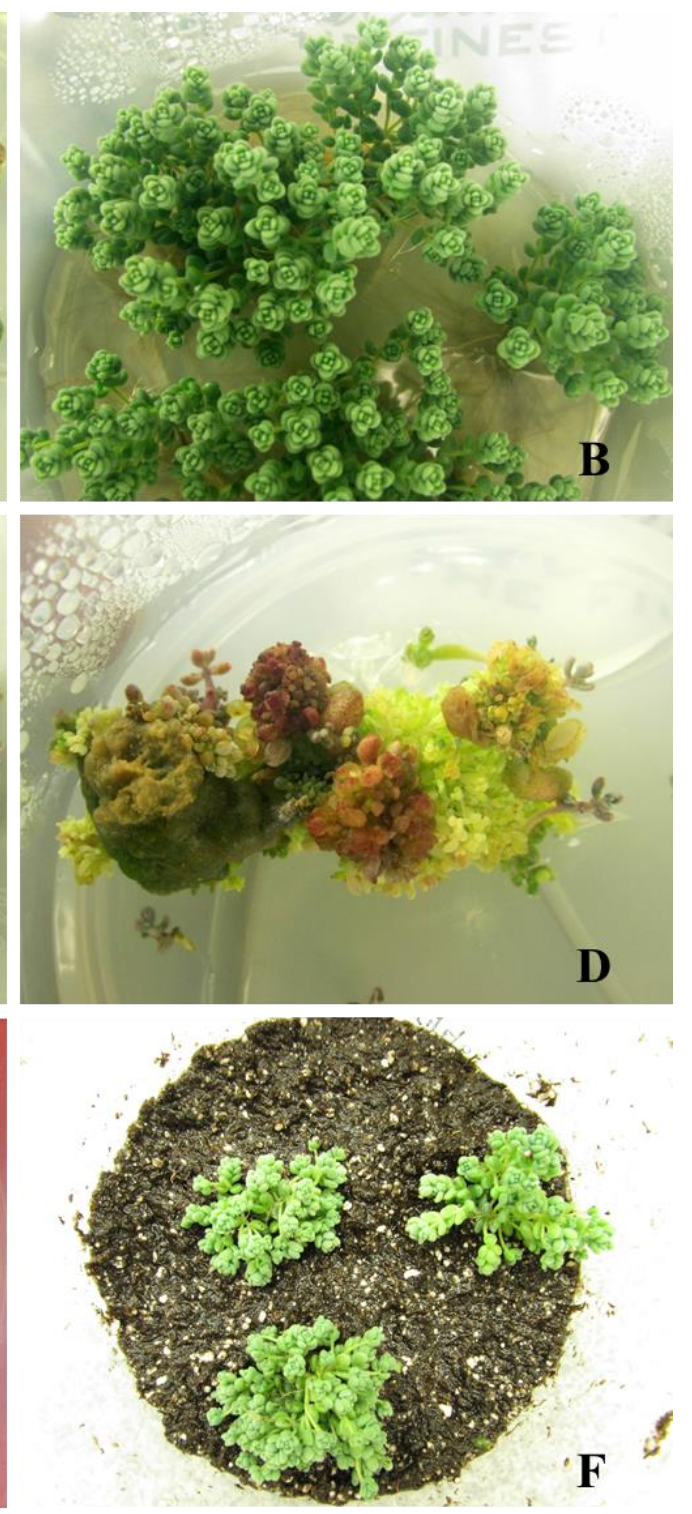

Figure 1- In vitro propagation of Sedum sarmentosum. A) Adventitious shoot regeneration from leaf explants cultured on MS medium with $8.0 \mu \mathrm{M}$ BA after 35 days of culture, B) Multiple shoot induction from shoot tip explants cultured on MS medium devoid of cytokinins, C) Shoot tip explants cultured on MS medium with $4.0 \mu \mathrm{M}$ BA, D) Shoot tip explants cultured on MS medium with 4.0 $\mu \mathrm{M}$ TDZ after 35 days of culture, E) Rooting on MS medium supplemented with $2.0 \mu \mathrm{M}$ IBA after 30 days of culture, F) Acclimatization of plantlets in a greenhouse medium 
Table 2- Effect of BA and TDZ on multiple shoot induction from shoot tip explants of Sedum sarmentosum after 35 days of culture.

\begin{tabular}{|c|c|c|c|}
\hline \multicolumn{2}{|c|}{ Conc. $\mu \mathrm{M}$} & \multirow{2}{*}{ Shoot regeneration (\%) } & \multirow{2}{*}{$\begin{array}{l}\text { Number of shoots } \\
\text { explant }\end{array}$} \\
\hline BA & TDZ & & \\
\hline 0.0 & 0.0 & $100 \pm 0.0^{\mathrm{a}}$ & $25.4 \pm 1.3^{\mathrm{a}}$ \\
\hline 2.0 & 0.0 & $100 \pm 0.0^{\mathrm{a}}$ & $5.8 \pm 0.6^{\mathrm{e}}$ \\
\hline 4.0 & 0.0 & $95.5 \pm 1.1^{\mathrm{b}}$ & $6.2 \pm 0.4^{\mathrm{e}}$ \\
\hline 8.0 & 0.0 & $91.0 \pm 1.2^{\mathrm{c}}$ & $5.4 \pm 0.3^{\mathrm{e}}$ \\
\hline 0.0 & 2.0 & $100 \pm 0.0^{\mathrm{a}}$ & $18.1 \pm 1.1^{\mathrm{b}}$ \\
\hline 0.0 & 4.0 & $100 \pm 0.0^{\mathrm{a}}$ & $14.2 \pm 0.8^{\mathrm{c}}$ \\
\hline 0.0 & 8.0 & $100 \pm 0.0^{\mathrm{a}}$ & $11.4 \pm 0.7^{\mathrm{d}}$ \\
\hline
\end{tabular}

Means \pm SE within a column followed by the same letters are not significantly different using Duncan's multiple range test at $\mathrm{p} \leq 0.05$.

Shoot tip explants also produced several pigmented shoots in the presence of TDZ (Fig. 1D). Cytokinins have been shown to enhance anthocyanin accumulation in in vitro cultures of Ajuga reptans (Callebaut et al. 1997), Arabidopsis thaliana (Deikman and Hammer 1995), and Malus sieversii f. niedzwetzkyana (Ji et al. 2015). The regenerated shoots rooted $(100 \%)$ with a mean number of 9.4 roots per shoot on auxins-free MS medium. Similar results have been reported in $S$. erythrostichum (Yoon et al. 2002) and S. sarmentosum (Ahn and Lee 2004; Lee et al. 2006). Addition of lower concentrations of IAA or IBA to the MS medium significantly enhanced mean number of roots per shoot. The highest number of (17.6) roots per shoot was obtained on MS medium supplemented with $2.0 \mu \mathrm{M}$ IBA after 30 days of culture (Fig. 1E, Table
3). The mean number of roots reduced on MS medium supplemented with high concentrations of IBA $(4.0$ and $8.0 \mu \mathrm{M})$. Higher concentrations of NAA (4.0 and $8.0 \mu \mathrm{M})$ inhibited rooting, whereas it induced multiple shoots. Of the three auxins tested, the best rooting response was observed with IBA followed by IAA and NAA. Regenerated plantlets were successfully acclimatized in the greenhouse with $100 \%$ survival rate (Fig. 1F). Overall, phytohormone-free MS basal medium and MS medium containing $8.0 \mu \mathrm{M}$ BA were the most suitable for axillary shoot multiplication and adventitious shoot regeneration of $S$. sarmentosum, respectively. The developed protocol could be utilized for Agrobacterium-mediated genetic transformation, large-scale clonal propagation and secondary metabolites extraction studies.

Table 3- Rooting response of regenerated shoots of Sedum sarmentosum cultured MS medium with different concentrations of auxins after 30 days of culture.

\begin{tabular}{|c|c|c|c|c|}
\hline \multicolumn{3}{|c|}{ Auxins $(\mu \mathrm{M})$} & \multirow{2}{*}{$\begin{array}{l}\text { Root induction } \\
(\%)\end{array}$} & \multirow{2}{*}{$\begin{array}{l}\text { No. of roots } \\
\text { shoot }\end{array}$} \\
\hline IAA & IBA & NAA & & \\
\hline 0.0 & 0.0 & 0.0 & $100 \pm 0.0^{\mathrm{a}}$ & $9.4 \pm 0.5^{\mathrm{c}}$ \\
\hline 2.0 & 0.0 & 0.0 & $100 \pm 0.0^{\mathrm{a}}$ & $12.3 \pm 0.5^{\mathrm{b}}$ \\
\hline 4.0 & 0.0 & 0.0 & $100 \pm 0.0^{\mathrm{a}}$ & $13.5 \pm 0.8^{\mathrm{b}}$ \\
\hline 8.0 & 0.0 & 0.0 & $100 \pm 0.0^{\mathrm{a}}$ & $8.1 \pm 0.7^{\mathrm{c}}$ \\
\hline 0.0 & 2.0 & 0.0 & $100 \pm 0.0^{\mathrm{a}}$ & $17.6 \pm 1.0^{\mathrm{a}}$ \\
\hline 0.0 & 4.0 & 0.0 & $100 \pm 0.0^{\mathrm{a}}$ & $13.7 \pm 1.2^{\mathrm{b}}$ \\
\hline 0.0 & 8.0 & 0.0 & $100 \pm 0.0^{\mathrm{a}}$ & $9.3 \pm 0.6^{\mathrm{c}}$ \\
\hline 0.0 & 0.0 & 2.0 & $31.3 \pm 1.6^{\mathrm{b}}$ & $3.6 \pm 0.4^{\mathrm{d}}$ \\
\hline 0.0 & 0.0 & 4.0 & $0.0 \pm 0.0^{\mathrm{c}}$ & $0.0 \pm 0.0^{\mathrm{e}}$ \\
\hline 0.0 & 0.0 & 8.0 & $0.0 \pm 0.0^{c}$ & $0.0 \pm 0.0^{\mathrm{e}}$ \\
\hline
\end{tabular}

Means \pm SE within a column followed by the same letters are not significantly different using Duncan's multiple range test at $\mathrm{p} \leq 0.05$. 


\section{ACKNOWLEDGEMENT}

This article was supported by the KU Research Professor Program of Konkuk University.

\section{REFERENCES}

Ahn JH, Lee SY. Effects of growth regulators on callus induction and plant regeneration from leaf explants of Sedum sarmentosum. J Plant Biotechnol. 2004; 31: 25-29.

Alaiwi WA, Josekutty PC, Goldman SL, Potlakayala SD, Sairam RV. Efficient in vitro propagation of Centaurea montana L. Propag Ornam Plants. 2011; 11: 40-43.

Callebaut A, Terahara N, de Haan M, Decleire M. Stability of anthocyanin composition in Ajuga reptans callus and cell suspension cultures. Plant Cell Tiss Org Cult. 1997; 50: 195-201.

Deikman J, Hammer PE. Induction of anthocyanin accumulation by cytokinins in Arabidopsis thaliana. Plant Physiol. 1995; 108: 47-57.

He A, Wang M, Hao H, Zhang D, Lee KH. Hepatoprotective triterpenes from Sedum sarmentosum. Phytochemistry. 1998; 49: 2607-2610.

Huetteman CA, Preece JE. Thidiazuron: a potent cytokinin for woody plant tissue culture. Plant Cell Tiss Org Cult. 1993; 33: 105-119.

Jeong BR, Sivanesan I. Direct adventitious shoot regeneration, in vitro flowering, fruiting, secondary metabolite content and antioxidant activity of Scrophularia takesimensis Nakai. Plant Cell Tiss Org Cult. 2015; 123: 607-618.

Jeong BR, Sivanesan I. Micropropagation, berberine content and antitumor activity of Jeffersonia dubia (Maxim.) Benth et Hook. Plant Cell Tiss Org Cult. 2016; 124: 453-458.

Ji XH, Wang YT, Zhang R, Wu SJ, An MM, Li M, Wang CZ, Chen XL, Zhang YM, Chen XS. Effect of auxin, cytokinin and nitrogen on anthocyanin biosynthesis in callus cultures of red-fleshed apple (Malus sieversii f. niedzwetzkyana). Plant Cell Tiss Org Cult. 2015; 120: 325-337.

Jung HJ, Kang HJ, Song YS, Park EH, Kim YM, Lim CJ. Anti-inflammatory, anti-angiogenic and antinociceptive activities of Sedum sarmentosum extract. J Ethnopharmacol. 2008; 116: 138-143.

Lee SY, Ahn JH, Kim HJ. Factors affecting shoot multiplication and rooting from cutting and in vitro node culture of Sedum sarmentosum. Korean J Hortic Sci Technol. 2006; 24: 43-47.

Lee SY, Ahn JH, Kim HJ. Factors influencing callus and shoot formation from in vitro propagation of Sedum sarmentosum. Hortic Environ Biotechnol. 2009; 50: 576-581.
Magyar-Tabori K, Dobranszki J, Taeixeira da Silva JA, Bulley SN, Hudak I. The role of cytokinins in shoot organogenesis in apple. Plant Cell Tiss Org Cult. 2010; 101: 251-267.

Mendi YY, Curuk P, Kocaman E, Unek C, Eldogan S, Gencel G, Cetiner S. Regeneration of begonia plantlets by direct organogenesis. Afr J Biotechnol. 2009; 8: 1860-1863.

Murashige T, Skoog F. A revised medium for rapid growth and bio assays with tobacco tissue cultures. Physiol Plant. 1962; 15: 473-497.

Prakash S, Elangomathavan R, Seshadri S, Kathiravan $\mathrm{K}$, Ignacimuthu S. Efficient regeneration of curcuma amada Roxb. plantlets from rhizome and leaf sheath explants. Plant Cell Tiss Org Cult. 2004; 78: 159165.

Sivanesan I, Jeong BR. Direct adventitious shoot regeneration from cotyledonary explants of Jeffersonia dubia Benth et. Hook. Propag Ornam Plants. 2013; 13: 46-48.

Sivanesan I, Ko CH, Lee JP, Jeong BR. Influence of cytokinins on adventitious shoot regeneration from leaf and petiole explants of Ajuga multiflora Bunge. Propag Ornam Plants. 2011; 11: 156-158.

Van Staden J, Zazimalova E, George EF. Plant growth regulators II: Cytokinins, their analogues and antagonists. In: George EF, Hall MA, De Klerk GJ (eds) Plant propagation by tissue culture, 3rd edn. Springer, Dordrecht; 2008. p. 205-226.

Yang C, Qin Y, Sun X, Yuan S, Lin H. Propagation of Sedum spectabile Boreau in leaf culture in vitro. Not Bot Horti Agrobot Cluj Napoca. 2012; 40: 101-112.

Yoon ES, Jeong JH, Choi YE. Recovery of Bastaresistant Sedum erythrostichum via Agrobacteriummediated transformation. Plant Cell Rep. 2002; 21: 70-75.

Received: November 25, 2015; Accepted: April 01, 2016. 